\title{
Unit of Catalytic Activity Concentration
}

National Cancer Institute

\section{Source}

National Cancer Institute. Unit of Catalytic Activity Concentration. NCI Thesaurus. Code C67365.

A unit of measurement of catalytic activity of the component in the unit volume of the system. The term catalytic concentration is accepted for use in clinical chemistry. Use of the term level as a synonym for concentration is deprecated. In describing a quantity, concentration must be clearly differentiated from content. 